\title{
HYPONATRAEMIA IN CIRRHOSIS- PREVALENCE AND CORRELATION WITH THE COMPLICATIONS OF CIRRHOSIS
}

\author{
Anusuya Meganathan'1, V. Santosh Kumar²
}

1Associate Professor, Department of Medicine, Government Stanley Medical College and Hospital, The Tamilnadu Dr. MGR Medical University, Chennai, Tamilnadu.

2Postgraduate Student, Department of Medicine, Government Stanley Medical College and Hospital, The Tamilnadu Dr. MGR Medical University, Chennai, Tamilnadu.

\begin{tabular}{l}
\hline ABSTRACT \\
BACKGROUND \\
Hyponatraemia is one of the complications in cirrhotic patients, occurring in more than one-third of the patients with chronic liver \\
disease and is believed to be caused by defective water homeostasis. The objective of our study is to establish the prevalence of \\
hyponatraemia in cirrhosis and to investigate if hyponatraemia predicts a rate of severity of complications in cirrhosis.
\end{tabular}

\section{MATERIALS AND METHODS}

A cross-sectional study was done in patients diagnosed with cirrhosis by a combination of clinical, biochemical and radiological findings. Demographic data and biochemical parameters including serum sodium levels were recorded at the time of admission or at the time of presentation in the outpatient department and patients were stratified into three groups: Group A- serum sodium < 130 mmoL; Group B- serum sodium between 131 - 135 mmol/L; Group C- serum sodium > 136 mmol/L. A detailed case report proforma was used for data collection for each patient.

\section{RESULTS}

Hundred patients were included in the study. 44 patients had serum sodium level of $<130 \mathrm{mmol} / \mathrm{L}$ (Group A), 26 patients had serum sodium 131 - $135 \mathrm{mmol} / \mathrm{L}$ (Group B) and 30 patients noted to have serum sodium > $136 \mathrm{mmol} / \mathrm{L}$ (Group C). Majority of Group A patients belonged to 31 - 40 years of age (34\%) and male gender (77\%). Group A patients had rising serum bilirubin levels of 10.01 to $20 \mathrm{mg} / \mathrm{dL}$ (34\%) compared to Group B and C (3.85\% and 3.3\% respectively). 84\% of Group A patients had serum albumin $<3.5 \mathrm{~g} / \mathrm{dL}$. Blood urea levels $>40 \mathrm{mg} / \mathrm{dL}$ and serum creatinine $>1.3 \mathrm{mg} / \mathrm{dL}$ are associated with $>50 \%$ of Group A patients. 37 patients had worsening hepatic encephalopathy in Group A. 38\% of Group A are associated with spontaneous bacterial peritonitis. 95\% of Group A patients had portal hypertension compared to 65\% of Group B and 11\% of Group C. The incidence of class 3 Child-Turcotte Pugh score was significantly higher in Group A (70.28\%). High MELD score (20 - 29) is associated with Group A patients (43.18\%).

\section{CONCLUSION}

This study was undertaken to establish serum sodium as an independent variable in the prognosis of patients with decompensated liver disease, irrespective of the aetiology. MELD Na scores calculated using serum sodium values have been recently found to supersede MELD scores to determine prognosis. By comparing MELD vs. MELD Na scores, this study concludes that MELD Na scores have been found to be more significant as a prognostic marker in patients with cirrhosis and its complications.

\section{KEYWORDS}

Cirrhosis, Portal Hypertension, Hyponatraemia, Coagulopathy, Hepatorenal Syndrome, Spontaneous Bacterial Peritonitis.

HOW TO CITE THIS ARTICLE: Meganathan A, Kumar VS. Hyponatraemia in cirrhosis- prevalence and correlation with the complications of cirrhosis. J. Evolution Med. Dent. Sci. 2018;7(18):2197-2201, DOI: 10.14260/jemds/2018/494

\section{BACKGROUND}

Cirrhosis can be defined as a dynamic process associated with fibrosis and alteration of normal liver structure into architecturally abnormal nodules.

Hyponatraemia is a common complication, occurring in more than one-third of patients with chronic liver disease and is believed to be caused by defective water homeostasis. Hyponatraemia may be of two types; hypovolaemic hyponatraemia or hypervolaemic hyponatraemia. ${ }^{1}$

'Financial or Other Competing Interest': None.

Submission 07-09-2017, Peer Review 11-04-2018,

Acceptance 18-04-2018, Published 30-04-2018.

Corresponding Author:

Dr. Anusuya Meganathan,

\#351, Konnur High Road,

C-47, Sunnyvale Apartments,

Ayanavaram, Chennai-600023.

E-mail: anusuyarubi@gmail.com

DOI: $10.14260 /$ jemds $/ 2018 / 494$
Hypervolaemic hyponatraemia is more common and is associated with low serum sodium levels and expansion of the extracellular fluid volume. ${ }^{2}$ It may occur spontaneously or as a result of administering excessive fluids that are hypotonic in nature. It can also occur due to other complications of cirrhosis, such as bacterial infections. On the other hand, hypovolaemic hyponatraemia is less common and characterised by reduced sodium levels without the presence of ascites and oedema, often secondary to overzealous diuretic therapy. ${ }^{3}$

Dilutional hyponatraemia in cirrhotic patients is usually associated with a decreased ability to excrete appropriate water in urine due to various factors. The most important factor is increased synthesis of vasopressin 4 due to hypovolaemia caused by decreased effective circulating volume secondary to splanchnic vasodilation. ${ }^{5}$ 
Patients who have End Stage Liver Disease with Volume Overload Status have-

- Decreased urine sodium values.

- Decreased total serum sodium values.

- Increase in total body water content.

Sodium values of less than $130 \mathrm{mEq} / \mathrm{L}$ carry a poorer prognosis, whereas values less than $120 \mathrm{mEq} / \mathrm{L}$ indicates impending hepatorenal syndrome.6,7

The neurological manifestations may not be seen in all patients of cirrhosis with hyponatraemia8; however, the presence of hyponatraemia has a huge negative impact on hepatic encephalopathy in these patients. ${ }^{9,10}$

Hyponatraemia in cirrhosis is associated with an increased morbidity and mortality. Studies suggest that hyponatraemia is a very important prognostic indicator in cirrhosis when included in the model for end-stage liver disease (MELD) score in those cirrhotic patients awaiting liver transplantation. ${ }^{11,12,13}$

Despite a large amount of medical literature suggesting the role of serum sodium as a prognostic factor in cirrhosis, the clinical significance of serum sodium levels and whether it is associated with a higher rate of specific complications in cirrhosis is not lucid. Only few studies have been undertaken to assess the correlation between serum sodium levels with prevalence and severity of complications of liver cirrhosis. ${ }^{14,15}$

There is no study conducted in the Indian subcontinent so far on this topic, which makes this study pertinent.

Hyponatraemia is probably more common among our patients because:

Most Indian liquid diets are not sodium rich and the tropical climate aggravates the amount of sodium lost in sweat.

\section{Aims and Objectives}

The aim of this study is to establish the prevalence of hyponatraemia in cirrhosis and to investigate if hyponatraemia predicts an increased rate and severity of complications in cirrhosis.

\section{MATERIALS AND METHODS}

\section{Place of Study}

Department of General Medicine, Govt. Stanley Medical College and Hospital.

\section{Study Design}

A cross-sectional study.

\section{Study Population}

100.

\section{Study Period}

March 2016 to August 2016.

\section{Inclusion Criteria}

1. Age $\geq 18$ years.

2. Patients diagnosed by a combination of clinical/biochemical and radiological findings: Patients with clinical signs of liver cell failure; clinical features of portal hypertension, hypoalbuminaemia and reversal of $\mathrm{A} / \mathrm{G}$ ratio; deranged prothrombin time and international normalised ratio (INR); ultrasound abdomen showing surface nodularity, coarse/ altered echotexture, parenchymal inhomogeneity in the liver with/ without ascites alone or with the features of portal hypertension like portal vein diameter $\geq 13 \mathrm{~mm}$, presence of collaterals and splenomegaly $\mathrm{OR}$

3. Patients diagnosed with histological diagnosis of cirrhosis.

\section{Exclusion Criteria}

The Patients with following comorbidities have been excluded-

1. Cardiac failure.

2. Cerebrovascular accident.

3. Acute CNS infections.

4. Hepatocellular carcinoma.

\section{Data Collection}

After obtaining informed consent, age, gender, risk factors and vital parameters were recorded in all patients.

History and clinical examination was done with special emphasis on the presence of jaundice and signs and symptoms of liver cell failure and complications of cirrhosis.

The patient was assessed and investigated for the presence and severity of the complications like Ascites, Hepatic encephalopathy, Spontaneous bacterial peritonitis (SBP), Hepatorenal syndrome and Upper GI bleed.

\section{Investigations Included}

- Serum Sodium.

- $\quad$ Liver Function Test.

- Renal Function Test.

- Prothrombin Time (PT), INR, activated partial thromboplastin time (aPTT).

- USG abdomen for hepatoportal system and to rule out mild ascites.

- Doppler for splenoportal axis.

- Upper gastrointestinal endoscopy.

- Ascitic fluid cytology.

- Ascitic fluid culture and sensitivity.

- Chest x-ray.

- Urine routine microscopy.

Patients were stratified into three groups: Group A (Serum sodium < $130 \mathrm{mmol} / \mathrm{L}$ ), Group B (Serum sodium 131 - $135 \mathrm{mmol} / \mathrm{L}$ ) and Group C (Serum sodium > $136 \mathrm{mmol} / \mathrm{L}$ ).

Severity of the liver disease assessed according to ChildTurcotte Pugh score, MELD score and MELD Na score.

\section{Data Analysis}

The collected data were analysed with IBM. SPSS statistics software 23.0 version. To describe about the data descriptive statistics, mean and SD were used. For multiple group comparison analysis, one-way ANOVA with Tukey's Post-Hoc test was used. For analysis of categorical variables, Fisher's Exact Test is used. In the above statistical tools, the probability value of .05 is considered as significant level.

\section{RESULTS}

For purposes of better comparison and understanding the effects of hyponatraemia, our study population of 100 patients have been divided into 3 groups on the basis of 
serum sodium levels as Group A $<130 \mathrm{mmol} / \mathrm{L}$, Group B 131 $135 \mathrm{mmol} / \mathrm{L}$ and Group C > $136 \mathrm{mmol} / \mathrm{L}$ levels. The prevalence of hyponatraemia in these groups are 44\%, $26 \%$ and $30 \%$ respectively (Table 1). The association between the level of hyponatraemia in cirrhosis and various factors such as age, gender, biochemical values as well as other complications of cirrhosis has been compared using these groups (Table 2). Majority of the Group A patients belonged to 31 - 40 years age and male gender. The association between the study groups and age and gender status is considered not statistically significant. Serum albumin of $<3.5$ $\mathrm{g} / \mathrm{dL}$ is found in $84 \%$ of Group A patients, $9 \%$ of Group B patients and $13 \%$ of Group C patients. Prolongation of INR $<2$ is associated with $52 \%$ of Group A cases, $7 \%$ of Group B and $6 \%$ of Group C patients. Similarly, blood urea levels of $>100$ $\mathrm{mg} / \mathrm{dL}$ is found in $13 \%$ of Group A patients. 38\% of Group A patients had $>2 \mathrm{mg} / \mathrm{dL}$ of serum creatinine levels. Similarly, $84 \%$ of Group A patients were associated with > 20 MELD scoring system and $72 \%$ of Group A patients belonged to $>30$ MELD Na score (Table 2). It is clearly evident that as hyponatraemia worsens, the liver function and renal function would decline which is evidenced by the significant association of hyponatraemia with parameters like Total bilirubin, Direct bilirubin, Serum albumin, INR, Urea,
Creatinine, MELD and MELD Na scores (Table 2). Majority of the Group A ( $\mathrm{n}=16,36.36 \%)$ patients had hepatorenal syndrome. The incidence of Portal Hypertension was 95\% in patients with severe hyponatraemia (Group A). It was noted that $81 \%$ of Group A patients were categorised into Class C Child-Turcotte Pugh score. Majority of the Group A ( $\mathrm{n}=37$, $84.09 \%$ ) patients had hepatorenal syndrome. It is seen that the incidence of complications like hepatic encephalopathy, hepatorenal-syndrome, spontaneous bacterial peritonitis and portal hypertension are more in severe hyponatraemia (Group A) (Table 3).

\begin{tabular}{|c|c|c|c|}
\hline Groups & Description & Number & \begin{tabular}{|l|} 
Percentage \\
\end{tabular} \\
\hline Group A & $\begin{array}{l}\text { Serum Sodium } \\
\leq 130 \mathrm{mmol} / \mathrm{L}\end{array}$ & 44 & 44 \\
\hline Group B & $\begin{array}{c}\text { Serum Sodium } \\
\text { Between 131- } \\
\text { 135mmol/L }\end{array}$ & 26 & 26 \\
\hline Group C & $\begin{array}{c}\begin{array}{c}\text { Serum Sodium } \\
\geq 136 \mathrm{mmol} / \mathrm{L}\end{array} \\
\end{array}$ & 30 & 30 \\
\hline & Total & 100 & 100 \\
\hline
\end{tabular}

\begin{tabular}{|c|c|c|c|c|c|c|}
\hline Characteristics & Groups & Mean & $\begin{array}{l}\text { Standard } \\
\text { Deviation }\end{array}$ & F-value & $\begin{array}{c}\text { P-value (One-Way ANOVA with } \\
\text { Tukey's Post-Hoc Test) }\end{array}$ & $\begin{array}{c}\text { Statistical } \\
\text { Significance }\end{array}$ \\
\hline \multirow{3}{*}{ Age } & $\mathrm{A}$ & 45 & 11 & \multirow{3}{*}{2.11} & \multirow{3}{*}{ 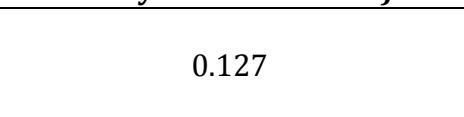 } & \multirow{3}{*}{ Not Significant } \\
\hline & $\mathrm{B}$ & 48 & 9 & & & \\
\hline & $\mathrm{C}$ & 50 & 11 & & & \\
\hline \multirow{3}{*}{ T.B } & A & 10.59 & 7 & \multirow{3}{*}{26.07} & \multirow{3}{*}{0.0005} & \multirow{3}{*}{ Significant } \\
\hline & B & 3.8 & 3.3 & & & \\
\hline & $\mathrm{C}$ & 2.72 & 2.4 & & & \\
\hline \multirow{3}{*}{ D.B } & A & 7.02 & 4.8 & \multirow{3}{*}{26.01} & \multirow{3}{*}{0.0005} & \multirow{3}{*}{ Significant } \\
\hline & $\mathrm{B}$ & 2.16 & 2.9 & & & \\
\hline & $\mathrm{C}$ & 1.45 & 1.5 & & & \\
\hline \multirow{3}{*}{ SGOT } & $\mathrm{A}$ & 100.98 & 79.6 & \multirow{3}{*}{2.14} & \multirow{3}{*}{0.123} & \multirow{3}{*}{ Not Significant } \\
\hline & B & 76.23 & 41.9 & & & \\
\hline & $\mathrm{C}$ & 72.63 & 54.3 & & & \\
\hline \multirow{3}{*}{ SGPT } & $\mathrm{A}$ & 68.07 & 50.7 & \multirow{3}{*}{1.14} & \multirow{3}{*}{0.323} & \multirow{3}{*}{ Not Significant } \\
\hline & $\mathrm{B}$ & 54.58 & 53.7 & & & \\
\hline & $\mathrm{C}$ & 48.77 & 65.8 & & & \\
\hline \multirow{3}{*}{ ALP } & $\mathrm{A}$ & 287.77 & 133.4 & \multirow{3}{*}{0.84} & \multirow{3}{*}{0.431} & \multirow{3}{*}{ Not Significant } \\
\hline & $\mathrm{B}$ & 344.27 & 291.9 & & & \\
\hline & $\mathrm{C}$ & 281.27 & 184.6 & & & \\
\hline \multirow{3}{*}{ Albumin } & A & 2.93 & 0.6 & \multirow{3}{*}{5.78} & \multirow{3}{*}{0.004} & \\
\hline & B & 3.24 & 0.6 & & & Significant \\
\hline & $\mathrm{C}$ & 3.42 & 0.6 & & & \\
\hline & $\mathrm{A}$ & 2.12 & 0.6 & & & \\
\hline INR & $\mathrm{B}$ & 1.47 & 0.4 & 24.66 & 0.0005 & Significant \\
\hline & $\mathrm{C}$ & 1.38 & 0.4 & & & \\
\hline & $\mathrm{A}$ & 53.91 & 34.5 & & & \\
\hline Urea & B & 27.46 & 14 & 6.48 & 0.002 & Significant \\
\hline & $\mathrm{C}$ & 33.42 & 40.4 & & & \\
\hline & A & 1.89 & 1.3 & & & \\
\hline Creatin & $\mathrm{B}$ & 1.1 & 0.5 & 3.21 & 0.045 & Significant \\
\hline & $\mathrm{C}$ & 1.38 & 1.8 & & & \\
\hline & $\mathrm{A}$ & 3.55 & 0.9 & & & \\
\hline $\mathrm{K}$ & $\mathrm{B}$ & 3.89 & 0.8 & 1.58 & 0.209 & Not Significant \\
\hline & $\mathrm{C}$ & 5.01 & 6.3 & & & \\
\hline & $\mathrm{A}$ & 27.7 & 8 & & & \\
\hline MELD & $\mathrm{B}$ & 15.86 & 6.7 & 33.02 & 0.0005 & Significant \\
\hline & $\mathrm{C}$ & 14.51 & 8 & & & \\
\hline
\end{tabular}




\begin{tabular}{|c|c|c|c|c|c|c|}
\hline \multirow{3}{*}{ MELD Na } & $\mathrm{A}$ & 33.32 & 5.9 & \multirow{2}{*}{70.96} & \multirow{2}{*}{0.0005} & Significant \\
\cline { 2 - 4 } & $\mathrm{B}$ & 19.88 & 5.9 & & \\
\cline { 2 - 4 } & $\mathrm{C}$ & 15.62 & 8.1 & & & \\
\hline
\end{tabular}

Note: Post-hoc test has been done and the statistical significance has been checked by Tukey's post-hoc test Table 2. Comparison of Groups with Various Characteristics

\begin{tabular}{|c|c|c|c|c|c|c|c|}
\hline Sl. No. & Complications & Grade & $\begin{array}{c}\text { Group A } \\
(\mathrm{n}=44)\end{array}$ & $\begin{array}{c}\text { Group B } \\
(\mathrm{n}=26)\end{array}$ & $\begin{array}{c}\begin{array}{c}\text { Group C } \\
(n=30)\end{array} \\
\end{array}$ & $\begin{array}{c}\text { P-value } \\
\text { (As Per Fisher's Exact Test) }\end{array}$ & Significance \\
\hline \multirow[t]{5}{*}{1} & $\begin{array}{c}\text { Hepatic } \\
\text { encephalopathy }\end{array}$ & NIL & 7 (15.91\%) & $23(88.46 \%)$ & $29(96.67 \%)$ & $<0.0001$ & \multirow{5}{*}{ Significant } \\
\hline & & 1 & $7(15.91 \%)$ & $2(7.69 \%)$ & $0(0 \%)$ & & \\
\hline & & 2 & $16(36.36 \%)$ & $0(0 \%)$ & $0(0 \%)$ & & \\
\hline & & 3 & $7(15.91 \%)$ & $1(3.85 \%)$ & $1(3.33 \%)$ & & \\
\hline & & 4 & $7(15.91 \%)$ & $0(0 \%)$ & $0(0 \%)$ & & \\
\hline \multirow[t]{2}{*}{2} & $\begin{array}{l}\text { Hepatorenal } \\
\text { syndrome }\end{array}$ & No & 28 (63.64\%) & $25(96.15 \%)$ & 28 (93.33\%) & 0.0005 & \multirow[t]{2}{*}{ Significant } \\
\hline & & Yes & $16(36.36 \%)$ & $1(3.85 \%)$ & $2(6.67 \%)$ & & \\
\hline \multirow[t]{2}{*}{3} & $\begin{array}{c}\text { Spontaneous } \\
\text { bacterial peritonitis }\end{array}$ & No & 27 (61.36\%) & $24(92.31 \%)$ & $25(83.33 \%)$ & 0.0078 & \multirow{2}{*}{ Significant } \\
\hline & & Yes & $17(38.64 \%)$ & $2(7.69 \%)$ & $5(16.67 \%)$ & & \\
\hline \multirow[t]{2}{*}{4} & Portal hypertension & No & $2(4.55 \%)$ & $9(34.62 \%)$ & $19(63.33 \%)$ & $<0.0001$ & \multirow{2}{*}{ Significant } \\
\hline & & Yes & $42(95.45 \%)$ & $17(65.38 \%)$ & $11(36.67 \%)$ & & \\
\hline \multirow[t]{3}{*}{5} & $\begin{array}{l}\text { Child-Turcotte Pugh } \\
\text { score }\end{array}$ & A & $0(0 \%)$ & $7(26.92 \%)$ & $19(63.33 \%)$ & $<0.0001$ & \multirow{3}{*}{ Significant } \\
\hline & & $\mathrm{B}$ & $8(18.18 \%)$ & $16(61.54 \%)$ & $8(26.67 \%)$ & & \\
\hline & & $\mathrm{C}$ & $36(81.82 \%)$ & $3(11.54 \%)$ & $3(10.00 \%)$ & & \\
\hline
\end{tabular}

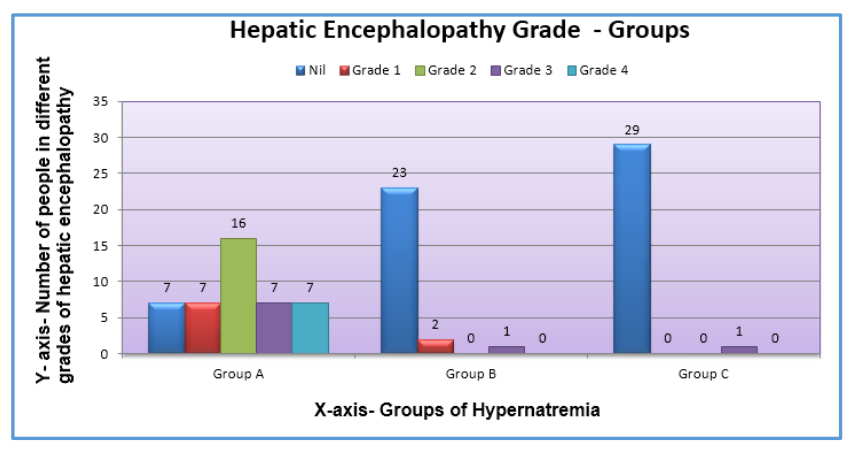

Figure 1. Hepatic Encephalopathy Grade - Groups

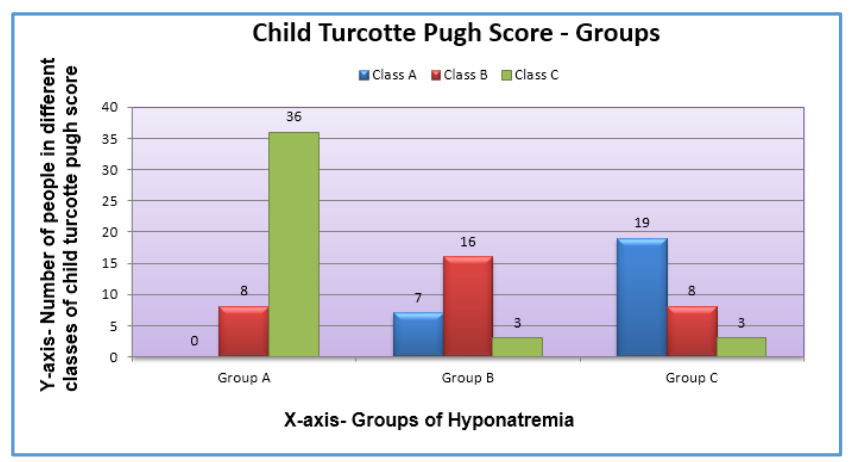

Figure 2. Child-Turcotte Pugh Score

\section{DISCUSSION}

In our study group of 100 patients, $44 \%$ had serum sodium $<130$ mmol (Group A), 26\% had 131 - 135 mmol (Group B) and $30 \%$ had serum sodium $>136 \mathrm{mmol}$ (Group C). Majority of the Group A patients belonged to the age group of $31-40$ years and of the male gender. The association between these variables and hyponatraemia is however not statistically significant.

Increasing Bilirubin levels $>10 \mathrm{mg} / \mathrm{dL}$ associated with severe hyponatraemia was noted in Group A. Similarly, significantly a high level of direct Bilirubin levels was also observed in Group A. Although, increased liver enzymes SGOT $>100 \mathrm{U} / \mathrm{L}$ and SGPT > $57 \mathrm{U} / \mathrm{L}$ was also associated with severe hyponatraemia in $44 \%$ of Group A patients, a statistical significance could not be established. Thus, serum Bilirubin but not SGPT/ SGOT has more significance with regard to the severity of hyponatraemia in cirrhosis.

Serum albumin of $<3.5 \mathrm{~g} / \mathrm{dL}$ is found in $84 \%$ of Group A patients, $9 \%$ of Group B and 13\% of Group C patients. This establishes a clear association between serum albumin levels and the severity of hyponatraemia. Similar findings were observed, and a significant association ascertained with INR. Prolongation of INR > $2 \%$ was found in $57 \%$ of Group A patients, but only amongst $7 \%$ and $6 \%$ of patients of Groups $\mathrm{B}$ and $\mathrm{C}$ respectively. Likewise, blood urea levels of $>100$ $\mathrm{mg} / \mathrm{dL}$ is found in $13 \%$ of Group A patients and 38\% of Group A patients had $>2 \mathrm{mg} / \mathrm{dL}$ of serum creatinine levels.

85\% of Group A patients had hepatic encephalopathy of varying degrees between grades 1 - 4, while $38 \%$ were found to have spontaneous bacterial peritonitis. The incidence of hepatorenal syndrome was also significantly higher in Group A compared to Group B (9.45 times higher) or Group C. ${ }^{16}$ The incidence of Portal Hypertension was $95 \%$ in patients with severe hyponatraemia of Group A. It was noted that $81 \%$ of Group A patients were categorised into Class C Child-Turcotte Pugh score. Similarly, $84 \%$ of Group A patients were associated with $>20$ MELD scoring system and $72 \%$ of Group A patients belonged to $>30$ MELD Na score. Hence, a clear statistical significance has been established between the above-mentioned factors and the severity of hyponatraemia in cirrhosis. 


\section{CONCLUSION}

Hyponatraemia in cirrhosis is associated with an increase in mortality and morbidity. Studies suggest that hyponatraemia is a very important prognostic indicator in cirrhosis when included in MELD score in those patients waiting for liver transplantation. Hyponatraemia also has high propensity to cause Osmotic demyelination syndrome with severe neurological dysfunction shortly after liver transplantation.

In our study group, the prevalence of hyponatraemia as per sodium < $130 \mathrm{mmol} / \mathrm{L}, 131-135 \mathrm{mmol} / \mathrm{L}$ and $>136$ mmol/L levels are $44 \%, 26 \%$ and $30 \%$ respectively. The association between the study groups and age and sex distribution is not statistically significant. Our study also established that severe hyponatraemia was associated with worsening jaundice, portal hypertension, higher grades of encephalopathy, increasing incidence of hepatorenal syndrome and spontaneous bacterial peritonitis.

Patients with moderate and severe hyponatraemia had higher Child Pugh and MELD scores in comparison to those in the study group with either mild hyponatraemia or normal sodium values. MELD Na scores have shown a greater significance in establishing and association as well as assessing the severity of the hyponatraemia.

Our study established the increased prevalence of hyponatraemia in cirrhosis and also worsening sodium levels are associated with the complications of cirrhosis.

So early identification of hyponatraemia in cirrhosis can be helpful for prompt and appropriate treatment, thereby attenuating the morbidity and mortality associated with the disease.

\section{REFERENCES}

[1] Kim JH, Lee JS, Lee SH, et al. The association between the serum sodium level and the severity of complications in liver cirrhosis. Korean J Intern Med 2009;24(2):106-12.

[2] Adrogué HJ, Madias NE. Hyponatremia. N Engl J Med 2000;342(21):1581-9.

[3] Fernandez-Esparrach G, Sanchez-Fueyo A, Gines P, et al. A prognostic model for predicting survival in cirrhosis with ascites. J Hepatol 2001;34(1):46-52.

[4] Hecker R, Sherlock S. Electrolyte and circulatory changes in terminal liver failure. Lancet 1956;268(6953):1121-5.

[5] Schrier RW, Arroyo V, Bernardi M, et al. Peripheral arterial vasodilation hypothesis: a proposal for the initiation of renal sodium and water retention in cirrhosis. Hepatology 1988;8(5):1151-7.
[6] Gines P, Guevara M. Hyponatremia in cirrhosis: Pathogenesis, clinical significance and management. Hepatology 2008;48(3):1002-10.

[7] Janičko M, Veselíny E, Abraldes JG, et al. Serum sodium identifies patients with cirrhosis at high risk of hepatorenal syndrome. Z Gastroenterol 2013;51(7):628-34.

[8] Corona G, Giuliani C, Parenti G, et al. Moderate hyponatremia is associated with increased risk of mortality: evidence from a meta-analysis. Poster session presented at: European Congress of Endocrinology, 2013 April 27 - May 1: Copenhagen, Denmark. PLoS One 2013;8(12):e80451.

[9] Restuccia T, Gómez-Ansón B, Guevara M, et al. Effects of dilutional hyponatremia on brain organic osmolytes and water content in patients with cirrhosis. Hepatology 2004;39(6):1613-22.

[10] Cordoba J, Gottstein J, Blei AT. Chronic hyponatremia exacerbates ammonia-induced brain edema in rats after portacaval anastomosis. J Hepatol 1998;29(4):589-94.

[11] Biggins SW, Kim WR, Terrault NA, et al. Evidencebased incorporation of serum sodium concentration into MELD. Gastroenterology 2006;130(6):1652-60.

[12] Zhang JY, Qin CY, Jia JD, et al. Serum sodium concentration profile for cirrhotic patients and its effect on the prognostic value of the MELD score. Zhonghua Gan Zang Bing Za Zhi 2012;20(2):108-11.

[13] Forman LM, Lucey MR. Predicting the prognosis of chronic liver disease: an evolution from child to MELD. Mayo End-stage Liver Disease. Hepatology 2001;33(2):473-5.

[14] Sersté T, Gustot T, Rautou PE, et al. Severe hyponatremia is a better predictor of mortality than MELDNa in patients with cirrhosis and refractory ascites. J Hepatol 2012;57(2):274-80.

[15] Borroni G, Maggi A, Sangiovanni A, et al. Clinical relevance of hyponatraemia for the hospital outcome of cirrhotic patients. Digest Liver Dis 2000;32(7):605-10.

[16] Guevara M, Baccaro ME, Torre A, et al. Hyponatremia is a risk factor of hepatic encephalopathy in patients with cirrhosis: a prospective study with timedependent analysis. Am J Gastroenterol 2009;104(6):1382-9. 